European Journal of Logistics, Purchasing and Supply Chain Management

Vol.8 No.3, pp.39-49, August 2020

Published by ECRTD UK

ISSN 2054-0930 (Print), ISSN 2054-0949 (Online)

\title{
PATIENT SATISFACTION AND OPERATIONS MANAGEMENT: A SERVICE DOMINANT LOGIC APPROACH
}

\author{
${ }^{a}$ Mohammed Hejazi, b Torky Althaqafi \\ ${ }^{a}$ Collage of Business Administration, University of Business and Technology, Saudi Arabia \\ a Email: m.hejazi@ubt.edu.sa \\ ${ }^{b}$ College of Business, University of Jeddah, Saudi Arabia \\ b Email: althaqafi@live.com
}

\begin{abstract}
The purpose of this paper is to involve patients in making decisions by applying Service Dominant Logic (SDL) to healthcare. The conceptual model in this paper uses two constructs to link the collaboration among stakeholders and the patient as an end user. Based on SDL, the study suggests that patient satisfaction is influenced by the relation between healthcare stakeholder interactions and collaboration among all agents in the healthcare network. This study suggests that educating and training the medical staff is an essential antecedent to healthcare stakeholders' collaboration, which in turn leads to improved clinical and process quality in healthcare institutions, and greater patient satisfaction. The research is based upon a review of complementary theoretical and empirical literature on SDL and the healthcare industry. The research target for this paper is large hospitals and their networks in Saudi Arabia.
\end{abstract}

KEYWORDS: stakeholders, service dominant logic, patient satisfaction, clinical and process quality, operations management

\section{INTRODUCTION}

Healthcare is struggling today to achieve and maintain patient satisfaction. Patients are satisfied when they receive the correct diagnosis and treatment of their illness combined with compassion and clear operation management on the part of the healthcare provider. Patients' satisfaction conveys their opinion about the healthcare service they have received, but the inclusion of their opinion of their medical care has been underdeveloped since the 1980s (Sitzia \& Wood, 1997). Many prior studies in the literature have addressed the patient satisfaction concept. Nevertheless, Liz and Lesley (2009) reviewed this literature and indicated that patient satisfaction lacks both conceptual and theoretical development. Most of these studies have adopted the ideas in the customer satisfaction concept without addressing the appropriate theoretical grounds. Therefore, this study adopts Service Dominant Logic (SDL) for two purposes. First, SDL is used in this study as a theoretical background that supports the concept of patient satisfaction. Second, the adoption of SDL as a new paradigm in the healthcare environment can introduce the idea that the patient is a partner in the process of delivering healthcare, and not simply a receiver of the service. 
European Journal of Logistics, Purchasing and Supply Chain Management

Vol.8 No.3, pp.39-49, August 2020

Published by ECRTD UK

ISSN 2054-0930 (Print), ISSN 2054-0949 (Online)

Importantly, a significant amount of research in the literature has investigated the factors that influence patient satisfaction (e.g., Marley, Collier, \& Meyer Goldstein, 2004). For example, studies have found that the value of the services customers have received affects their satisfaction (Heskett, Jones, Loveman, Sasser, \& Schlesinger, 1994). Further, satisfaction implies “...the probability that the customer is confident enough about the level of quality received that he or she would recommend another person to use this service provider" (Marley, Collier, \& Meyer Goldstein, 2004). Such confidence can be viewed as a source of value creation, which is the principal core of SDL.

According to Vargo and Lusch (2004), SDL is a service-centered alternative to the traditional goods-centered paradigm used to understand economic exchange and value creation that has been identified as an appropriate philosophical foundation for the development of service science. SDL is based on the notion that service is the fundamental basis of value creation through operational practices. Thus, practice is exchanged for services (i.e., by service systems) and, when involved, goods are service-provision vehicles. In short, SDL claims that service is crucial and demands a high level of interaction on the customer's part. Because this study targeted healthcare and the hospital environment, patient satisfaction is used rather than satisfaction.

The focus in explaining the interaction among agents in healthcare has ignored the role of the patients as one of the players in this type of interaction. Thus, the patient should be involved in the interactions among different agents in the healthcare operational system. Patients are co-producers of value and should assume responsibility in part of their healthcare service. Relevantly, Lusch and Vargo (2006) defined service as "...the application of specialized competences (knowledge and skills), through deeds, processes, and performances for the benefit of another entity, or the entity itself." Moreover, SDL asserts that customers are seen increasingly as active creators of value, as they interact with providers, have access to more information, and are more empowered (Prahalad \& Ramaswamy, 2004). As a result, SDL is the most appropriate theoretical framework in this study because patients interact with other healthcare stakeholders to increase their level of satisfaction. In fact, the interaction aforementioned in this paper will be presented as collaboration among stakeholders. Thus, this study's primary contribution is rethinking the way healthcare delivery can allow patients to have control over their healthcare service. Further, the study contributes to the healthcare literature by examining key variables from the technology adoption literature (Davis, 1989) in the context of SDL. Thus, this study extends these aformentioned variables with SDL to allow the consumer and producer to work together on the same level. In the technology adoption literature, technology refers to intermediary instruments that afford the creation, use, and knowledge of tools, machines, techniques, crafts, systems, or methods of organization to solve a problem or perform a specific function. It can refer also to the collection of such tools, machinery, and procedures as part of operation management. Thus, technology eases humans' life through adoption of certain aspects that facilitate humans' control of the natural environment (Davis, Bagozzi, \& Warshaw,1989). Accordingly, the purpose of this paper is to design a theoretical model that identifies the relation among the operational practices. The study also attempts to answer the following question; how does all healthcare stakeholders' collaboration contribute to creating value in patient stasfaction? 
European Journal of Logistics, Purchasing and Supply Chain Management

Vol.8 No.3, pp.39-49, August 2020

Published by ECRTD UK

ISSN 2054-0930 (Print), ISSN 2054-0949 (Online)

The remainder of the paper is structured as follows. The next section presents the development of propositions. The subsequent section presents the study's theoretical foundations and develops the research model and propositions. The following section provides the research design and methodology, and finally, implications are discussed.

\section{RELEVANT LITERATURE AND DEVELOPMENT OF PROPOSITIONS}

This study focuses on the group unit of interactions among stakeholders because healthy interactions and communication require collective and coordinated action. Thus, the degree to which an employee can use knowledge management systems and share knowledge in the healthcare organization calls for concurrent actions of interdependent others (Holahan et al., 2004).

\section{Medical training and education, and clinical quality}

Coulson (2010) insisted that continuous education and learning has two major benefits that include the improvement of clinical outcomes, and enhancement of care provided overall. Further, he added that learning allows and ensures that healthcare professionals adopt best practices. Importantly, Coulson (2009) also noted that the healthcare environment faces many changes and challenges, such as developments in medical practice, new drugs, additional regulations introduced, and others. Consequently, these challenges require healthcare providers to be updated continuously about new changes in their environment. For example, healthcare professionals' carrier requires the use of support tools (PCs, mobile phones, tablets, and others) to make their job easier. Thus, continuous training and education is crucial to face the challenges in the healthcare environment.

Medical training and education can be defined as the process by which healthcare providers are equipped to adopt and cope with the changes in the healthcare environment and match the requirements of advancing science and technology (Coulson, 2010; Li, Benton, \& Leong, 2002). Medical training and education refer to the process that allows qualified health professionals to improve their professional practice or healthcare outcomes effectively (O'Brien et al., 2001; Coulson-Thomas, 2010). Li, Benton, and Leong indicated that hospitals need to empower their workforce through education and training. Importantly, workers should be provided with on-thejob training, staff skill development, and job enrichment (Deming, 1982). Moreover, Criteria (1995) suggested that increasing staff training at hospitals is crucial to ensure hospitals' service quality. From the service quality literature, it is useful to split service quality into technical and process quality (Marley, Collier, \& Goldstein, 2004). Technical quality is essentially, "what" the customer receives from the service provider. In the healthcare field, technical quality is referred to as clinical quality (Collier, 1994). Accordingly, clinical quality refers to medical procedures' technical quality and their results' accuracy (Marley, Collier, and Goldstein, 2004). Clinical quality can be defined as hospitals' ability to achieve high standards of patient healthcare through medical diagnosis, procedures, and treatment to ultimately have positive physical or physiological effects on patients (Groonroos, 1990). 
European Journal of Logistics, Purchasing and Supply Chain Management

Vol.8 No.3, pp.39-49, August 2020

Published by ECRTD UK

ISSN 2054-0930 (Print), ISSN 2054-0949 (Online)

Further, the changes and challenges in the healthcare environment mentioned above require healthcare professionals to receive continuous education and training. Interestingly, these challenges influence the delivery of care (Griscti \& Jacono, 2006). As a result, the lack of continuous education and training programs at healthcare facilities influences clinical quality adversely. From the previous discussion, proposition 1 addresses medical training and education's influence on clinical quality:

Proposition 1: Medical education and training has a direct and positive effect on clinical quality.

\section{Medical training and education, and process quality}

Marley, Collier, and Goldstein (2004) argued that process quality differs from clinical quality, in that it focuses on the service (nontechnical) delivery process provided during and outside the medical procedures. Thus, process quality is not associated with treatment outcomes, but with internal activities instead. Importantly, it measures hospitals' internal operations (Theokary \& Justin Ren, 2011). For instance, process quality involves the level of personalization and patientservice provider interaction, the delivery of medication and food to the patient, the efficiency of admission and checkout, and the timeliness and accuracy of hospital bills. Consequently, process quality refers to the improvement of healthcare service quality overall that involves development of a strategy to resolve patient complaints and dissatisfaction, with the ultimate goal to motivate the patient to continue to use the hospital service (Marley, Collier, \& Meyer, 2004). Moreover, there is another difference between the two types of qualities. Process quality refers more to the managerial elements of the service quality. Therefore, hospitals' management can have more control over process quality than clinical quality.

Hence, training and education has a positive influence on service quality overall (Criteria, 1995), and as process quality is a dimension of service quality, the following proposition demonstrates the positive relation between process quality and medical education and training.

Proposition 2: Medical education and training has a direct and positive effect on process quality.

\section{Medical training and education, and healthcare stakeholders' collaboration}

Healthcare stakeholders include four entities: Employers; medical providers; payers, and patients. Collaborations among stakeholders are necessary for a fruitful and successful interaction among healthcare agents (Evans, 1994). Nevertheless, there are some factors that can interrupt the smoothness of the collaboration and interaction processes (San et al., 2005).

Importantly, empowering patients enhances the collaboration and interaction between them and others stakeholders, and Poon et al. (2007) encouraged patients to become active participants in their care. Interestingly, patients may bring health maintenance issues to busy clinicians' attention if they are given the opportunity to anticipate the discussions that may occur during the clinical encounter (Poon et al., 2007). Similarly, patients should ask questions about anything concerning 
European Journal of Logistics, Purchasing and Supply Chain Management

Vol.8 No.3, pp.39-49, August 2020

Published by ECRTD UK

ISSN 2054-0930 (Print), ISSN 2054-0949 (Online)

their health issue. For example, they should ask questions about the side effects and duration of medications their physicians prescribe. Consequently, patients should educate themselves about their health problems to communicate well with their physicians. (Trummer et al., 2006) asserted that improved communication with patients in major routine interactions in their care (admission, round wards, trainings, and discharge) will lead to better clinical results and greater patient satisfaction in many cases. Further, the authors discussed the importance of investing in staff training and reorganizing information and communication schemes that can be cost-effective interventions in hospital care.

Another example of empowering patients is encouraging them to speak up if they feel that the physician is discussing another patient's results mistakenly, because there is always room for errors. Sinha and Kohnke (2009) addressed the importance of patient's awareness, which "...implies the knowledge of a patient about the existence, diagnosis and treatment of his or her disease" condition in the healthcare environment.

From the forgoing, the following proposition demonstrates the relation between medical training and education:

Proposition 3: Medical education and training has a direct and positive effect on healthcare stakeholders' collaboration

\section{Clinical quality, process quality, and healthcare stakeholders' collaboration and utility}

Utility derives originally from the TAM model Davis (1989) and Davis, Bagozzi, and Warshaw (1989) introduced. The TAM model has been used extensively in the literature to address the producer's perspective, point of view, and behavior in accepting a new technology or system (Hernandez, Jimenez, \& Martí, 2009). Nevertheless, this study targets the consumer's point of view in the acceptance of service. More importantly, consumers (patients) are co-value creators of their healthcare service. As stated, such co-value derives from the interaction among stakeholders, particularly that between patients and other healthcare stakeholders. Further, value derives from empowering patients to make decisions about their healthcare service.

In addition, the accuracy of diagnosis, medical procedures, and treatment reflects the ability to perform several functions with high standards. This refers to the utility of the healthcare service together with the delivery of "what," which is the milestone of clinical quality. Similarly, process quality delivers the "how" of healthcare service and motivates patients to use the service. Thus, healthcare providers gain the patient's trust through their achievement of clinical and process quality. According to Ha and Stoel (2009), trust is a critical belief that contributes to the utility (usefulness) of service. Indeed, it has been argued that trust is a powerful antecedent to utility (Ha \& Stoel, 2009; Wu \& Chen, 2005).

From the discussion above, the following propositions are proposed: 
European Journal of Logistics, Purchasing and Supply Chain Management

Vol.8 No.3, pp.39-49, August 2020

Published by ECRTD UK

ISSN 2054-0930 (Print), ISSN 2054-0949 (Online)

Proposition 4: Healthcare stakeholders' collaboration has a direct effect on utility expectancy (usefulness).

Proposition 5: Clinical quality has a direct effect on utility expectancy (usefulness).

Proposition 6: Process quality has a direct effect on utility expectancy (usefulness).

Process quality, healthcare stakeholders' collaboration and convenience

As indicated earlier, empowering patients is a cornerstone of healthcare stakeholders' successful collaboration and interaction. According to Kumar, Ghildayal, and Shah (2011), perspectives about collaboration are critical, given the organizational structure of collated services, transdisciplinary focus, and the inclusion of diverse practices that enhance the interaction among stakeholders. Importantly, Brown (1990) introduced five dimensions for convenience in service. The convenience dimensions are time, place, acquisition, use and execution. Yoon \& Kim (2007) explained the five dimensions according to product orientation. However, we modified Brown's conceptualization of convenience to make it fit with our argument about service dominancy in healthcare. Accordingly, the dimensions are as follows:

1. Time dimension: service is provided at a time that is more convenient for the patient.

2. Place dimension: service may be provided in a place that is more convenient for the healthcare delivery.

3. Acquisition dimension: Firms may make it easier for the patient, financially and otherwise, to purchase their products.

4. Use dimension: Product may be made more convenient for the customer to use.

5. Execution dimension: The most obvious convenience is simply having someone provide the service for the consumer.

Based on the aforementioned discussion, we propose the following;

Proposition 7: Healthcare stakeholders' collaboration has a direct effect on convenience

Proposition 8: Process quality has a direct effect on convenience

\section{Utility expectancy, convenience, and patient satisfaction}

Based on the intention behavior relation from TAM (Davis, 1989), the Theory of Reasoned Action (Fishbein \& Ajzen,1975) and the Theory of Planned Behavior (Arzen,1991), we argue that patients' behavioral intention, or specifically, patients' intention to use a healthcare service from a certain healthcare provider is a predictor of their satisfaction. Based on the previous discussion, we propose the following:

Proposition 9: Utility expectancy has a direct positive effect on patient satisfaction. Proposition 10: Convenience has a direct positive effect on patient satisfaction. 
European Journal of Logistics, Purchasing and Supply Chain Management

Vol.8 No.3, pp.39-49, August 2020

Published by ECRTD UK

ISSN 2054-0930 (Print), ISSN 2054-0949 (Online)

\section{RESEARCH FRAMEWORK}

This study proposes ten propositions from which the research framework is developed (Figure 1). To our knowledge, no prior studies have combined SDL and TAM to rethink the delivery of healthcare and evaluate the level of patient satisfaction. Hence, the definitions of all of the constructs in the conceptual model are provided in the following table.

\begin{tabular}{|c|c|c|}
\hline Construct & Definition & References \\
\hline $\begin{array}{l}\text { Medical Training \& } \\
\text { Education }\end{array}$ & $\begin{array}{l}\text { The process by which healthcare } \\
\text { providers are equipped to adopt and cope } \\
\text { with changes in the healthcare } \\
\text { environment and match the requirements } \\
\text { of advancing science and technology }\end{array}$ & $\begin{array}{l}\text { Coulson (2010) } \\
\text { Li, Benton, and Leong } \\
(2002)\end{array}$ \\
\hline Clinical quality & $\begin{array}{l}\text { "What" is delivered in healthcare } \\
\text { service? Clinical quality refers to } \\
\text { hospitals" ability to achieve high } \\
\text { standards of patient health through } \\
\text { medical diagnosis, procedures, and } \\
\text { treatment that ultimately have positive } \\
\text { physical or physiological effects on } \\
\text { patients }\end{array}$ & $\begin{array}{l}\text { Marley, Collier, and } \\
\text { Meyer (2004) }\end{array}$ \\
\hline Process quality & $\begin{array}{l}\text { "How" healthcare service is delivered. } \\
\text { This refers to the improvement in } \\
\text { healthcare service quality overall, which } \\
\text { involves developing a strategy to resolve } \\
\text { patient complaints and dissatisfaction, } \\
\text { with the ultimate goal to motivate patients } \\
\text { to continue to use the hospital service }\end{array}$ & $\begin{array}{l}\text { Marley, Collier, and } \\
\text { Meyer (2004) }\end{array}$ \\
\hline $\begin{array}{l}\text { Healthcare } \\
\text { stakeholders, } \\
\text { collaboration }\end{array}$ & $\begin{array}{l}\text { Efficient, effective, and satisfying } \\
\text { interactions among healthcare } \\
\text { professions to offer optimum healthcare } \\
\text { services }\end{array}$ & $\begin{array}{l}\text { Bruner, Waite, and } \\
\text { Davey (2011), Chang, } \\
\text { Ma, Chiu, Lin, and Lee } \\
(2009)\end{array}$ \\
\hline $\begin{array}{l}\text { Utility expectancy } \\
\text { (Usefulness) }\end{array}$ & $\begin{array}{l}\text { Refers to the extent to which patients } \\
\text { have confidence and trust in using a } \\
\text { healthcare service }\end{array}$ & $\begin{array}{l}\text { Davis (1989) } \\
\text { Davis, Bagozzi, and } \\
\text { Warshaw (1989) } \\
\text { Venkatesh and Davis } \\
(2000) \\
\text { Yarbrough and Smith } \\
\text { (2007) } \\
\text { Liu and Ma (2005) } \\
\end{array}$ \\
\hline
\end{tabular}


European Journal of Logistics, Purchasing and Supply Chain Management Vol.8 No.3, pp.39-49, August 2020

Published by ECRTD UK

ISSN 2054-0930 (Print), ISSN 2054-0949 (Online)

\begin{tabular}{|l|l|l|}
\hline \multicolumn{1}{|c|}{$\begin{array}{c}\text { Convenience (ease of } \\
\text { use) }\end{array}$} & $\begin{array}{l}\text { Refers to the extent to which the } \\
\text { convenience of a new healthcare service } \\
\text { is associated with the application of this } \\
\text { service to patients }\end{array}$ & $\begin{array}{l}\text { Davis (1989) Davis, } \\
\text { Bagozzi, and Warshaw, } \\
1989) \\
\text { Venkatesh and Davis } \\
(2000) \\
\text { Yarbrough and Smith } \\
(2007) \\
\text { Liu and Ma (2005) } \\
\text { Hu and Stoel (2009) }\end{array}$ \\
\hline Patient Satisfaction & $\begin{array}{l}\text { Refers to how the patients judge their } \\
\text { hospital experience overall and whether } \\
\text { they would return for a future visit }\end{array}$ & $\begin{array}{l}\text { Marley, Collier, \& } \\
\text { Meyer (2004) }\end{array}$ \\
\hline
\end{tabular}

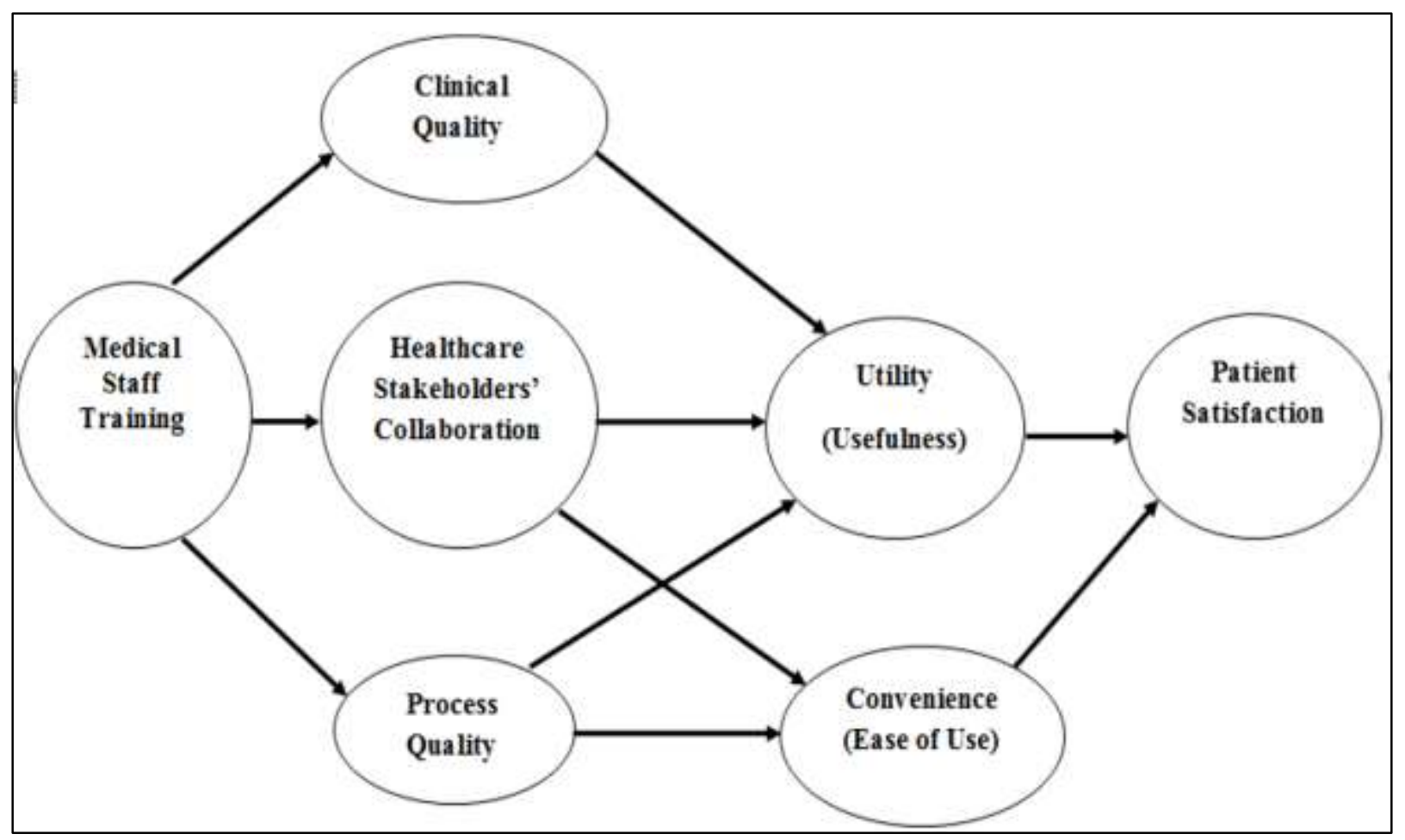

Figure 1- Research Conceptual Framework

\section{MEASUREMENT}

The study will measure patient satisfaction by asking hospitals' administrators for their coded data on patient satisfaction. As a result, the unit of analysis is at the individual level. This research is 
European Journal of Logistics, Purchasing and Supply Chain Management

Vol.8 No.3, pp.39-49, August 2020

Published by ECRTD UK

ISSN 2054-0930 (Print), ISSN 2054-0949 (Online)

conceptual in nature, but the motivation for using secondary data from hospitals' administrators is to employ them in a forthcoming empirical study. In addition, the following control variables will be used when the empirical study is conducted.

\section{Hospital Characteristics}

Hospital location and Strategy interaction: Refers to the interaction between urban/rural location and marketing strategy and the interaction between urban/rural location and operations strategy

Location: Urban vs. rural area

Hospital size: Refers to the hospital's actual size and number of beds

Hospital type: Distinguishes between profit vs. non-profit hospitals

Demand management: Refers to whether hospitals can accommodate a large number of patients

Hospital strategy: Refers to hospitals' coherent strategies that can be represented as the most appropriate combinations and interactions of the hospitals' operations strategies and marketing strategies

B. Patient demographics (Socioeconomic status): This control variable will classify the patients based on their socioeconomic status that measures such factors as education, income, type of occupation, and place of residence

\section{IMPLICATIONS}

This study has two important implications. First, it encourges reserchers to consider the patient as an essential component of healtcare service delivery. Further, it motivates mangers to develop new tools to measure and enhance patient satsfication.

\section{LIMITATION}

This paper is conceptual in nature, and empirical investigations are necessary to test the framework demonstrated here. Besides, the study focuses only on large hospitals, and other healthcare facilities should be included in future studies.

\section{REFERENCES}

Brown, L.G. (1990). Convenience in services marketing. Journal of Services Marketing, 4(1), 53 -59 .

Bruner, P., Waite, R., \& Davey, M.P. (2011). Providers' perspectives on collaboration. International Journal of Integrated Care (IJIC), 111-11.

Chang, W., Ma, J., Chiu, H., Lin, K., \& Lee, P. (2009). Job satisfaction and perceptions of quality of patient care, collaboration and teamwork in acute care hospitals. Journal of Advanced Nursing, 65(9), 1946-1955.

Collier, D.A. (1994). The service quality solution. Milwaukee, WI: Irwin Professional Publishing. 
European Journal of Logistics, Purchasing and Supply Chain Management Vol.8 No.3, pp.39-49, August 2020

Published by ECRTD UK

ISSN 2054-0930 (Print), ISSN 2054-0949 (Online)

Coulson-Thomas, C. (2010). Transforming productivity and performance in healthcare and other public services: How training and development could make a strategic contribution. Industrial and Commercial Training, 42.

Coulson-Thomas, C. (2009). Transforming healthcare. Cotoco, Southampton.

Criteria, A. (1995). Malcolm Baldrige National Quality Award, Gaithersburg, United States Department of Commerce, MD.

Davis, F.D. (1989). Perceived usefulness, perceived ease of use and user acceptance ofinformation technology. MISQ, 13, 319-39.

Davis, F.D., Bagozzi, R.P., \& Warshaw P.R. (1989). User acceptance of computer technology: A comparison of two theoretical models. Manage Sci, 35(8), 982-1003.

Deming, E.W. (1982). Improvement of quality and productivity through action by management. National Productivity Review, 1, 12-22.

Evans, J.A. (1994). The role of the nurse manager in creating an environment for collaborative practice. Holistic Nursing Practice, 8, 22 - 31.

Fishbein, M., \& Ajzen, I. (1975). Belief, attitude, intention, and behavior: An introduction to theory and research. Addison-Wesley.

Gill, L., \& White, L. (2009). A critical review of patient satisfaction. Leadership in Health Services, 22, 8-19.

Goldstein, S.M., Ward, P.T., Leong, G.K., \& Butler, T.W. (2002). The effect of location, strategy, and operations technology on hospital performance. Journal of Operations Management, 20, 63-75.

Griscti, O., \& Jacono, J. (2006). Effectiveness of continuing education programs in nursing: Literature review. Journal of Advanced Nursing, 55(4).

Groonroos, C. (1990). A service quality model and its marketing implications. In G. Clark (Ed.), Managing service quality, an IFS Executive Briefing. Kempston, Bedford, UK: IFS Publications, 13-18.

Ha, S., \& Stoel, L. (2009). Consumer e-shopping acceptance: Antecedents in a technology acceptance model. Journal of Business Research, 62(5).

Hernandez, B., Jimenez, J., \& Martí, M., J. (2009). Adoption vs acceptance of e-commerce: Two different decisions. European Journal of Marketing, 43(9-10), 1232-1245.

Heskett, J.L., Jones, T.O., Loveman, G.W., Sasser, W.E., \& Schlesinger, L.A. (1994). Putting the service-profit chain to work. Harvard Business Review, 72, 164-174.

Kumar, S., Ghildayal, N.S., \& Shah, R.N. (2011). Examining quality and efficiency of the US healthcare system. International Journal of Healthcare Quality Assurance, 24(5), 366388.

Li, L.X., Benton, W.C., \& Leong, G.K. (2002). The impact of strategic operations management decisions on community hospital performance. Journal of Operations Management, 20, 389-408

Liu, L., \& Ma, Q. (2005). The impact of service level on the acceptance of application service oriented medical records. Information \& Management, 42(8), 1121-1135. doi: 10.1016/j.im.2004.12.004

Lusch, R.F., \& Vargo, S.L. (2006). Service-Dominant Logic as a foundation for a general theory. In Lusch, R.F., Vargo, S.L., (Eds.) The Service-Dominant Logic of marketing: Dialog, debate, and directions. First ed. Armonk, NY: M.E. Shape, pp. 406-420. 
European Journal of Logistics, Purchasing and Supply Chain Management

Vol.8 No.3, pp.39-49, August 2020

Published by ECRTD UK

ISSN 2054-0930 (Print), ISSN 2054-0949 (Online)

O'Brien, M.A., Freemantle, N., Oxman, A.D., Wolf, F., Davis D.A., \& Herrin, J. (2001). Continuing education meetings and workshops: Effects on professional practice and healthcare outcomes. Cochrane Database of Systematic Reviews 2001, Issue 1.

Marley, K., Collier, D., \& Goldstein, S. (2004). The role of clinical and process quality in achieving patient satisfaction in hospital. Decision Sciences, 35, 349-369

Prahalad, C.K., \& Ramaswamy, V. (2004). Co-creation experiences: The next practice in value creation. Journal of Interactive Marketing, 18(3), pp. 5-14.

Poon, E.G., Wald, J., Schnipper, J.L., Grant, R., Gandhi, T.K., Volk, L.A., \& Middleton, B.

(2007). Empowering patients to improve the quality of their care: Design and implementation of a shared health maintenance module in a US integrated healthcare delivery network. Studies in Health Technology and Informatics, 129(Pt 2), 1002-1006.

San, M., Iacute, N.R., Iacute, G.L., Beaulieu, M.-D., \& Ferrada-Videla, M. (2005). The determinants of successful collaboration: A review of theoretical and empirical studies. Journal of Interprofessional Care, 19(Supplement 1), 132-147.

Sinha, K.K., \& Kohnke, E.J. (2009). Healthcare supply chain design: Toward linking the development and delivery of care globally. Decision Sciences, 40, 197-212.

Sitzia, J., \& Wood, N. (1997). Patient satisfaction: A review of issues and concepts. Social Science \& Medicine, 45(12), 1829-1843.

Sykes, T.A. et al. (2011). Explaining physicians' use of EMR systems and performance in the in the shakedown phase. Journal of the American Medical Informatics Association.

Theokary, C., \& Justin Ren, Z. (2011). An empirical study of the relations between hospital volume, teaching status, and service quality. Production and Operations Management, 20, 303-318.

Trummer, U.F., Mueller, U.O., Nowak, P., Stidl, T., Pelikan, J., \& Rgen, M. (2006). Does physician-patient communication that aims at empowering patients improve clinical outcome? Patient Education and Counseling, 61, 299-306.

Vargo, S., \& Lusch, F. 2004. Evolving to a new dominant logic for marketing. Journal of Marketing, 68, 1-17.

Wu, I., \& Chen, J. (2005). An extension of Trust and TAM model with TPB in the initial adoption of on-line tax: An empirical study. International Journal of Human-Computer Studies, 62(6), 784-808.

Yarbrough, A.K., \& Smith, T. (2007). Technology acceptance among physicians: A new take on TAM. Medical Care Research and Review, 64(6).

Yoon, C., \& Kim, S. (2007). Convenience and TAM in a ubiquitous computing environment: The case of wireless LAN. Electronic Commerce Research and Applications, 6(1), 102112. 